\title{
Influence of Carbohydrates, Mineral Nutrients and Plant Hormones in Alternate Bearing of Black Pepper (Piper nigrum L.)
}

\author{
K. S. Krishnamurthy ${ }^{*}$, S. J. Ankegowda, V. Srinivasan, S. Hamza \\ Indian Institute of Spices Research, Kozhikode, India. \\ Email: *kskrishnamurthy@gmail.com
}

Received July $30^{\text {th }}, 2013$; revised August $29^{\text {th }}, 2013$; accepted September $19^{\text {th }}, 2013$

Copyright (C) 2013 K. S. Krishnamurthy et al. This is an open access article distributed under the Creative Commons Attribution License, which permits unrestricted use, distribution, and reproduction in any medium, provided the original work is properly cited.

\begin{abstract}
Alternate bearing habit, a common phenomenon prevalent in some of the fruit trees is observed in black pepper variety Panniyur-1 also. In this study, an attempt was made to investigate the role of carbohydrates, mineral nutrients and plant hormones (IAA and zeatin riboside) in alternate bearing in Panniyur-1 variety. The experiment was conducted for three consecutive years at Murugarajendra estate, Madikeri, Karnataka, India $\left(12.42^{\circ} \mathrm{N}, 75.73^{\circ} \mathrm{E}\right)$. Carbohydrate, mineral nutrient and plant hormone (IAA and zeatin riboside) statuses of the leaves as well as fruiting branches (stem) were compared between good fruiting year (on year) and low fruiting year (off year). Results revealed that concentration of mineral nutrients in leaves was more during on year compared to off year while the reverse was true on the stem. Both stem and leaf metabolite levels at harvest were higher in off year compared to on year suggesting that remobilization of nutrients to the developing berries must have been affected during off year, thus leading to accumulation of more nutrients at harvest in off year compared to on year. Leaf had higher concentration of most of mineral nutrients compared to stem. Spraying of 1\% solution of complex fertilizer 19:19:19 (percent N:P:K) three times at an interval of 3 weeks from flower primordial initiation to flowering period enhanced the yield to the extent of around $30 \%$ during off year. Auxin to cytokinin ratio was 6.6 and 6.1 in on year and 6.3 and 5.7 in off year at flowering and 3 months after flowering respectively, suggesting that this ratio itself may not play a major role in flowering during on and off years, though the ratio was slightly more during on year. Results of the study indicate that efficient utilization of metabolites and nutrients in on year may render vine weak in the subsequent year coupled with poor remobilization into developing berries, which could make it an off year.
\end{abstract}

Keywords: Remobilization; Starch; IAA; Zeatin Riboside; Reducing Sugars; Essential Oil; Oleoresin

\section{Introduction}

The term alternate bearing refers to fruit bearing habit of some of the fruit trees such as mango, citrus, olives, pistachio, dates etc. and the same has been extended to black pepper also in this study. It is hypothesized that in alternate bearing behavior, yield in one year affects yield in the subsequent year. This bearing habit is also observed in predominantly cultivated black pepper hybrid Panniyur-1. In Panniyur-1, following a good crop, in the ensuing year very limited new vegetative growth takes place which generally bears inflorescence, thus limiting flower production. It is suggested that three mechanisms are apparently involved in the maintenance of the alternate

"Corresponding author. bearing condition in fruits: 1) flowering site limitations; 2) hormonal control; and 3) nutritional control [1]. Alternate bearing theory in pecan is that the flowering is first controlled by growth regulators produced by fruit and leaves, and then by the size of the carbohydrate pool near budbreak. Nitrogen reserves have also been proposed to be limiting after large crops, thus reducing return bloom [2]. In date palm, an off tree could be possibly identified by lower levels of leaf boron [3], thus highlighting the role of mineral elements controlling flowering. Evidence indicates that in some species, the young fruit somehow interferes with flower bud differentiation, imposing a flowering site limitation. As seedless fruits have little effect on next year's flowering, whereas seeded fruits are inhibitory, a role for seeds in alternate bearing was hypo- 
thesized in several tree crops [1]. The alternate bearing pattern associated with inflorescence bud abscission in "Kerman" pistachio may be a function of mid-season mobilization of stored carbohydrates in current-season stems resulting in stimulation of inflorescence bud abscission [4]. It has been frequently reported that the reproductive effort during the "on" year leads to a serious depletion of carbohydrate reserves and mineral nutrients. Carbohydrate starvation involves dramatic changes in gene expression. Alternate bearing could have an evolutionary significance also. Domestication of fruit trees would have eliminated natural stresses which would have resulted in irregular bearing. So, the alternate bearing may help in maintaining homeostasis [1]. Domestication theory could be applicable to black pepper also, as black pepper basically is a forest crop which was domesticated.

In black pepper though alternate bearing is not a common phenomenon, it is observed frequently in Panniyur1 hybrid. As this variety is highly yielding and very responsive to fertilizers and irrigation under optimum light conditions, nutrient exhaustion could be one of the reasons for such a behavior. So, nutrition is another aspect which may control flowering and fruit set. It has also been reported that auxins may have been involved in the fruit induced inhibition of flowering. A depletion of carbohydrates in flower buds in "on" year trees was found by some researchers during seed development [5]. It has been suggested that threshold levels of carbohydrates might be required for flower bud differentiation. Fruit set and abscission are closely dependent upon carbohydrate levels in some crops. But no reports are available on factors influencing alternate bearing in black pepper. Hence, the present investigation was undertaken with the objective of understanding the role of carbohydrate reserves as well as nutritional and hormonal influence on alternate bearing in black pepper variety Panniyur-1.

\section{Materials and Methods}

\subsection{Experimental Material and Experimental Site}

Black pepper variety Panniyur-1 was selected for the study as this variety shows alternate bearing behaviour. Experimental site was Murugarajendra estate, Madapur, Madikeri, Karnataka, India $\left(12.42^{\circ} \mathrm{N}, 75.73^{\circ} \mathrm{E}\right)$.

\subsection{Metabolites, Nutrients and Plant Hormones}

All recommended package of practices for cultivation of the crop were followed. In the absence of monsoon rains, the vines were irrigated at the basin during March to May at fortnightly intervals @ 50 litres per vine to maintain soil moisture at around $16 \%-17 \%$. Twenty vines which were about 15 years old were tagged for carbohydrate and hormone study. For carbohydrate and hormone estimations, leaves and stem from the fruiting branches of these tagged vines were collected just before flower initiation and also after the harvest of the crop. Youngest fully mature leaf samples were used for all the analyses.

\subsection{Quantification of Metabolites and Mineral Nutrients}

Leaf and stem samples were washed thoroughly in double distilled water, blotted and dried in oven at $55^{\circ} \mathrm{C}$ to a constant weight. The samples were then powdered using a powdering mill and were used for the analysis of carbohydrates, reducing sugars, starch and minerals by adopting standard procedures. Nitrogen was analysed through Kjeldal's method, phosphorus through vanado molybdate method and all the other elements through atomic absorption spectrophotometer (model 240FS) after wet oxidation of the tissue samples. Total carbohydrates, starch and reducing sugars were extracted and estimated by adopting the standard procedures as described by Sadasivam and Manickam [6].

\subsection{Extraction and Quantification of Plant Hormones}

Fresh samplesafter thorough washing in double distilled water were blotted, weighed $(250 \mathrm{mg})$ and extracted in $80 \%$ cold methanol $(10 \mathrm{ml})$, centrifuged at $10,000 \mathrm{rpm}$ for 20 minutes at $4^{\circ} \mathrm{C}$ and the supernatant was used for the assay of plant hormones. For IAA estimation, the methanol in the supernatant was removed by rotary flash evaporation system at $35^{\circ} \mathrm{C}$ and further extraction was done as per Aniket et al. [7] with minor modifications and estimated as per Glickmann and Dessaux [8] using Salkowski's reagent. For Quantification of zeatin riboside, the methanol in the supernatant was removed by rotary flash evaporation system at $35^{\circ} \mathrm{C}$, the residue was redissolved in $2 \mathrm{ml}$ methanol and $50-100 \mu \mathrm{l}$ of aliquot was used for estimation through indirect ELISA utilizing the antibody kit supplied by M/s Sigma Chemicals Ltd.

\subsection{Nutrient Solution Sprays}

For nutrient spray studies, 20 vines per treatment were given either water or $0.5 \%, 1.0 \%, 1.5 \%$ and $2 \%$ sprays of commercially available complex fertilizer mixture 19:19:19 (\%N:P:K) during flower primordialinitiation to flowering stage. The spray was given 3 times at an interval of 3 weeks and the spray was taken up after the harvest of a good crop, as the good crop is followed by a lean crop. Observation on yield and quality parameters was recorded after harvest of the crop. 


\subsection{Yield Parameters}

Spike length: Spike length was measured in at least 10 spikes from 10 vines in each treatment and expressed in $\mathrm{cm}$.

Number of spikes $\mathrm{m}^{-2}$ : Number of spikes present in $0.5 \mathrm{~m}^{2}$ area of the canopy was counted by holding a frame of $0.5 \mathrm{~m}^{2}$ area against the canopy and counting the number of spikes present inside the frame from 10 vines in each treatment and expressed as spikes $\mathrm{m}^{-2}$.

Berry yield: Fresh berries from 10 vines in each treatment (after harvest) were dried separately in oven at $60^{\circ} \mathrm{C}$ till it attained constant weight and expressed as $\mathrm{kg} \cdot$ vine $^{-1}$.

\subsection{Quality Parameters}

Essential oil and oleoresin from sundried berry samples were estimated by the ASTA method [9]. Essential oil was extracted by hydro distillation (using Clevenger trap for lighter than water type) of powdered berry sample and the oil collected was measured and expressed as percentage (volume/weight). Oleoresin was extracted from the powdered sample by cold percolation technique and the viscous mass obtained was regarded as oleoresin and expressed as percentage (weight/dry weight).

\section{Statistical Analysis}

Statistical analysis (ANOVA as well as t-test) was conducted using MSTATC package.

\section{Results and Discussion}

\subsection{Metabolite Levels}

Total carbohydrates, reducing sugars and starch were estimated in black pepper variety Panniyur-1 before flowering and immediately after harvest in on year as well as off year. In general, stem showed higher metabolite content compared to leaves. Both stem and leaf metabolite levels before flowering were higher in on year compared to that in off year (Figure 1) except for reducing sugars at flowering which was more in off year compared to on year. But the trend was reverse at harvest. Both stem and leaf metabolite levels at harvest were higher in off year compared to that in on year (Figure 2). Total stem carbohydrate content at flowering was $16.6 \%$ and $14.1 \%$

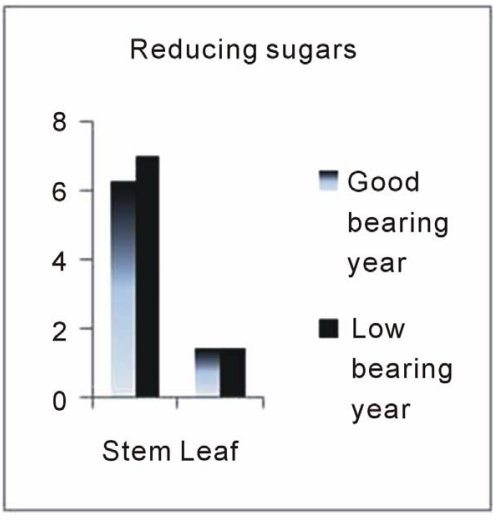

(a)

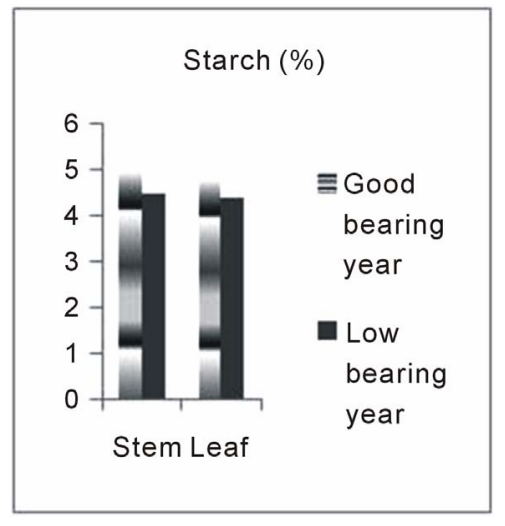

(b)

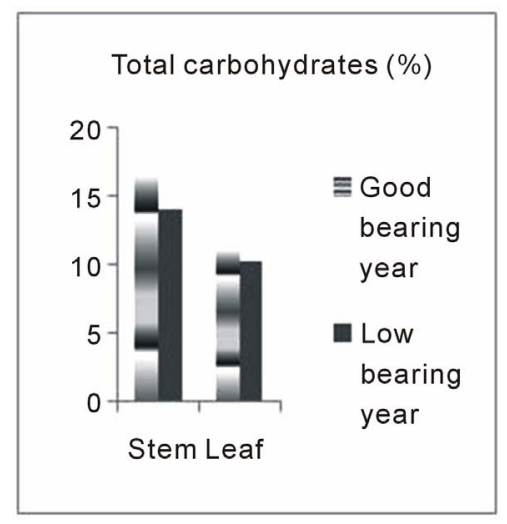

(c)

Figure 1. Metabolite levels before flowering.

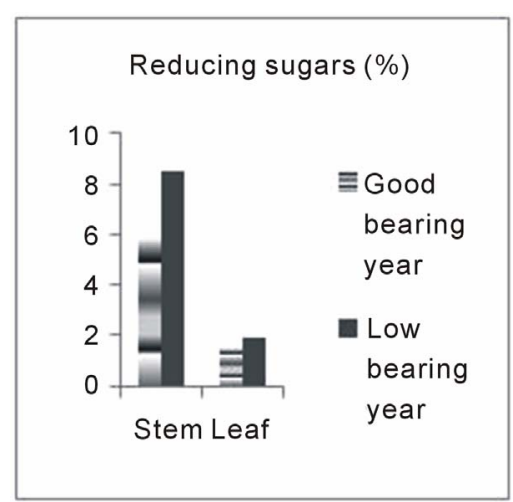

(a)

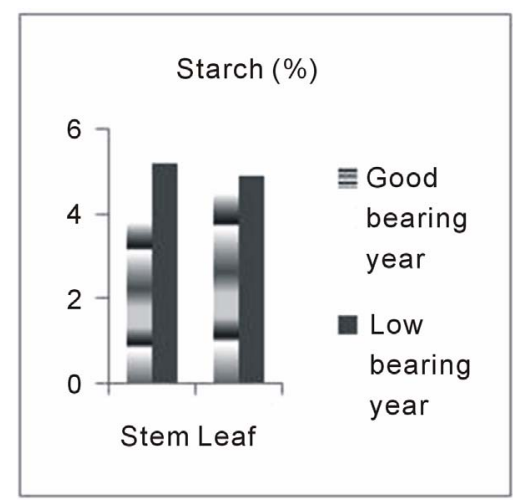

(b)

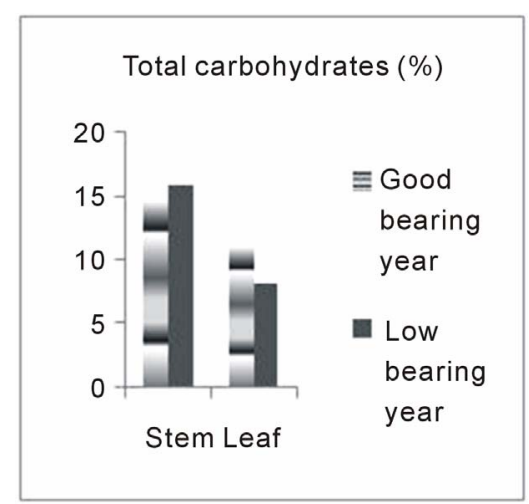

(c)

Figure 2. Metabolite levels after harvest. 
respectively during on and off years while it was $14.7 \%$ and $15.9 \%$ respectively during on and off years at harvest. Similarly, stem starch content at flowering was $5 \%$ and $4.5 \%$ respectively during on and off years while it was $3.8 \%$ and $5.2 \%$ respectively at harvest.

In mango, changes in reducing, non-reducing and total sugars, as well as starch, were lower in regular-bearing than alternate-bearing cultivars. In regular-bearing trees, reducing sugars were highest at fruit bud differentiation (FBD), declined during fruit development and increased at maturity. Non-reducing and total sugars followed a rise-and-fall pattern from FBD to maturity. In alternate bearing trees, reducing, non-reducing and total sugars increased during FBD to flowering, then decreased from fruit development to maturity. The starch content declined from FBD to maturity [10]. In the present study, metabolite status of the vines was high at flowering in on year compared to off year while at harvest, it was reverse. But reducing sugars content at flowering was less in on year as compared to off year. This indicates that carbohydrate status of the plant may have some influence on flowering in black pepper. This may be due to the fact that the stem may try to accumulate metabolites which were exhausted in on year. Later, once the threshold level is reached, it may be mobilized for growth. Hence, we may witness higher carbohydrate and starch levels at harvest during off year which can be utilized for flower and fruit production in the ensuing year, thus making it an on year.

It has been reported that stem carbohydrate content along with nitrate reductase activity and photosynthetic rate of juvenile black pepper plants can be considered as determinators of yield to identify high yielding black pepper vines in the juvenile stage itself which suggests a role for carbohydrates in flowering and productivity [11]. In olive, mannitol was higher than the other sugars and the content of mannitol in off-year was lower than that in on-year [12]. Spann et al. [4] reported that the alternate bearing pattern associated with inflorescence bud abscission in "Kerman" pistachio may be a function of midseason mobilization of stored carbohydrates in currentseason stems resulting in stimulation of inflorescence bud abscission. In black pepper also, mobilization of stem reserves to the developing fruits seems to be affected during off year.

But there are some reports which suggest no role for carbohydrates in flowering. Monerri et al. [13] reported that in sweet orange, carbohydrate reserves played little or no role over fruit set, which actually relied on current photosynthesis. Smith et al. [2] reported that crop load in pecan was not related to nonstructural carbohydrates, N, or $\mathrm{K}$ in the roots and shoots in the well-managed trees. Stored nonstructural carbohydrates, N, and K were not related to return bloom also. There are some instances where the developing fruits suppress flower production in the next season. For example in citrus, fruit growth suppresses CiFT (a flowering-related gene, citrus flowering locus $\mathrm{T}$ ) expression and decreases the flower number the next spring. Also, a long fruit-bearing period suppresses CiFT expression in vegetative shoots, thus limiting flower production [14]. But such a phenomenon was not observed in black pepper.

\subsection{Carbohydrates and Hormones}

Equal quantity of both stem and leaf samples was ground together for estimation of zeatin riboside (cytokinin), indole acetic acid (IAA) and total carbohydrates. Results revealed that the contents of all of them reduced 3 months after flowering compared to the contents at flowering both in on and off years but the reduction was very less in the off year compared to on year except for cytokinin in the off year which showed a small increase (Table 1). Total carbohydrates content reduced from $8.1 \%$ to $7.2 \%$ in on year (from flower initiation to 3 months after flowering) while the reduction was from $6.5 \%$ to $6.3 \%$ only in off year. Similarly, IAA content reduced from 732 to $570 \mathrm{ngg}^{-1}$ in on year and from 538 to $518 \mathrm{ngg}^{-1} \mathrm{FW}$ in off year.

Total carbohydrates decreased from $8.1 \%$ to $7.2 \%$, zeatin riboside from 111 to $93 \mathrm{ng}$ and IAA from 732 to 570 ng from flowering to three months after flowering in on year. But such a decrease was not evident in the off

Table 1. Total carbohydrates, indole acetic acid and zeatin riboside as influenced by bearing habit.

\begin{tabular}{|c|c|c|c|c|}
\hline Sl. No & Treatment & $\begin{array}{c}\text { Total } \\
\text { carbohydrates } \\
(\%)\end{array}$ & $\begin{array}{c}\text { IAA } \\
\text { (ng/g FW) }\end{array}$ & $\begin{array}{c}\text { Zeatin } \\
\text { riboside } \\
\text { (ng/g FW) }\end{array}$ \\
\hline \multicolumn{5}{|c|}{ Off year } \\
\hline 1 & $\begin{array}{l}\text { During flower } \\
\text { initiation }\end{array}$ & 6.5 & 538 & 85 \\
\hline 2 & $\begin{array}{l}3 \text { months after } \\
\text { flowering }\end{array}$ & 6.3 & 518 & 91 \\
\hline 3 & Mean & 6.4 & 528 & 88 \\
\hline \multicolumn{5}{|c|}{ On year } \\
\hline 4 & $\begin{array}{l}\text { During flower } \\
\text { initiation }\end{array}$ & 8.1 & 732 & 111 \\
\hline 5 & $\begin{array}{l}3 \text { months after } \\
\text { flowering }\end{array}$ & 7.2 & 570 & 93 \\
\hline \multirow[t]{4}{*}{6} & Mean & 7.7 & 651 & 102 \\
\hline & $\begin{array}{c}\mathrm{CD}(0.05) \\
\text { between } 1 \& 2\end{array}$ & NS & NS & NS \\
\hline & $\begin{array}{c}\mathrm{CD}(0.05) \\
\text { between } 4 \& 5\end{array}$ & 0.3 & 39.3 & 18.5 \\
\hline & $\begin{array}{c}\mathrm{CD}(0.05) \\
\text { between } 3 \text { \& } 6\end{array}$ & 0.42 & 31.1 & NS \\
\hline
\end{tabular}


year although both carbohydrates and IAA showed a slight decreasing trend while zeatin riboside showed a small increase (Table 1). This could be due to rapid utilization by the developing fruits (sinks) in the on year compared to off year. Plant hormones do play a role in alternate bearing in some fruit crops. There were significant differences in IAA, abscisic acid, $\mathrm{GA}_{3}$-like, and kinetin-like cytokinins between "on" and "off" cropping years in various tissues of olive trees. In Pistacia vera, IAA, zeatin and ABAlevels in the leaf were high in the first year (on year), and was low in the second year (off year) [15]. Baktir et al. [16] opined that the relative balances between $\mathrm{GA}_{3}$-like compound and abscisic acid concentrations of tissues may act as a key regulator of floral development and alternate bearing. Hegele et al. [17] reported hormonal regulation of flowering through maintenance of auxin cytokinin ratio. In the present study auxin to cytokinin ratio was 6.6 and 6.1 in on year and 6.3 and 5.7 in off year at flowering and 3 months after flowering respectively suggesting that this ratio may not play a major role in flowering during on and off years. Though the ratio was slightly high in on year the differences were not significant. Also, exogenous application of plant hormones (combination of auxin, gibberellin and cytokinin) during post flowering to early berry development stage did not improve per vine yield in black pepper (data not presented). It remains to be investigated if the yield per vine could be improved in off year through growth regulator sprays during flower primordial initiation stage as was done for nutrient spray in the present study.

\subsection{Leaf and Stem (Lateral Branch) Nutrient Levels in Relation to Alternate Bearing}

Major (N, P, K), secondary (Ca, Mg) and micro (Mg, Fe,
$\mathrm{Mn}, \mathrm{Zn}$ and $\mathrm{Cu}$ ) nutrients were quantified in leaves and stemsthree months after flowering during both on and off years. It was observed that $\mathrm{N}, \mathrm{K}, \mathrm{Fe}, \mathrm{Mn}$ and $\mathrm{Cu}$ were more in leaves in on year compared to off year while $\mathrm{P}$, $\mathrm{Ca}, \mathrm{Mg}$ and $\mathrm{Zn}$ were on Par. But the stem from off year had higher quantity of most of the nutrients compared to that from on year. It had higher $\mathrm{N}, \mathrm{P}, \mathrm{K}, \mathrm{Ca}, \mathrm{Mg}, \mathrm{Fe}, \mathrm{Mn}$, and $\mathrm{Zn}$ while only $\mathrm{Cu}$ was on par. In general, leaf had higher nutrient content compared to stem (Table 2).

When total carbohydrates, starch and reducing sugars were quantified in stem and leaves during on and off years three months after flowering, it was found that leaves had higher total carbohydrates in on year compared to off year while stem had higher content in off year compared to on year. Total carbohydrates in the stem ranged from $13.6 \%$ (on year) to $15.7 \%$ (off year) while in the leaves, it ranged from $6.5 \%$ (off year) to $7.9 \%$ (on year). Starch and reducing sugars in both leaves and stem were higher in off year compared to on year (Table 3). Berry yield (dry) was $6.1 \mathrm{~kg} \cdot \mathrm{vine}^{-1}$ during on year and $3.8 \mathrm{~kg} \cdot \mathrm{vine}^{-1}$ during off year.

\subsection{Leaf Nutrient Spray to Regulate Alternate Bearing}

Nutrient supplementation during pre-flowering stage (flower primordial initiation stage) is not a recommended practice in black pepper. Nutrients are provided at flowering initiation stage with the onset of monsoon during June I week. To investigate if spiking (flowering) can be improved in off year by providing nutrients during preflowering stage (flower primordial initiation to flowering period), three rounds (April II week, May I week and May IV week) of sprays of 19:19:19 complex fertilizer $(\% \mathrm{~N}: \mathrm{P}: \mathrm{K})$ were given. Four nutrient spray treatments $(0.5 \%, 1.0 \%, 1.5 \%$ and $2.0 \%$ nutrient solution of

Table 2. Nutrient element levels during on and off years.

\begin{tabular}{cccccccccc}
\hline Treatment & $\mathrm{N}(\%)$ & $\mathrm{P}(\%)$ & $\mathrm{K}(\%)$ & $\mathrm{Ca}(\%)$ & $\mathrm{Mg}(\%)$ & $\mathrm{Fe}(\mathrm{ppm})$ & $\mathrm{Mn}(\mathrm{ppm})$ & $\mathrm{Zn}(\mathrm{ppm})$ & $\mathrm{Cu}(\mathrm{ppm})$ \\
\hline Leaf-On year & 2.36 & 0.09 & 1.47 & 2.44 & 0.42 & 288.24 & 660.92 & 23.11 & 552.09 \\
Leaf-Off year & 2.05 & 0.09 & 1.03 & 2.55 & 0.39 & 181.42 & 549.67 & 22.92 & 488.54 \\
Stem-On year & 1.64 & 0.09 & 1.27 & 1.58 & 0.20 & 112.67 & 67.59 & 32.07 & 317.59 \\
Stem-Off year & 1.87 & 0.12 & 2.05 & 2.20 & 0.35 & 201.42 & 132.67 & 40.99 & 313.00 \\
CD $(0.05)$ & 0.21 & 0.02 & 0.40 & 0.33 & 0.06 & 66.2 & 57.6 & 3.8 & 49.3 \\
\hline
\end{tabular}

Table 3. Metabolite levels in on and off years during berry development period.

\begin{tabular}{ccccc}
\hline Treatment & Total carbohydrates $(\%)$ & Starch $(\%)$ & Reducing sugars $(\%)^{\text {Berry yield }\left(\mathrm{kg} \cdot \text { vine }^{-1}\right)}$ \\
\hline Leaf-On year & 7.9 & 5.3 & 2.2 & 6.1 \\
Stem-On year & 13.6 & 5.1 & 5.5 & 3.8 \\
Leaf-Off year & 6.5 & 5.8 & 2.6 & 8.3 \\
Stem-Off year & 15.7 & 5.8 & 0.51 & \\
CD $(0.05)$ & 0.62 & 0.45 & & \\
\hline
\end{tabular}


Alternate Bearing of Black Pepper (Piper nigrum L.)

19:19:19NPK complex fertilizer) were included with water spray as control. Among the nutrient sprays, $1.0 \%$ spray recorded the maximum berry yield $(5.4 \mathrm{~kg}$ dry yield vine $\left.{ }^{-1}\right)$ followed by $1.5 \%$ spray $\left(4.9 \mathrm{~kg} \cdot \mathrm{vine}^{-1}\right)$. Control recorded the least $\left(3.8 \mathrm{~kg} \cdot \mathrm{vine}^{-1}\right)$ which was on par with $2 \%$ spray $\left(3.9 \mathrm{~kg} \cdot \mathrm{vine}^{-1}\right)$. Spike length and number of spikes per $0.5 \mathrm{~m}^{2}$ were lowest in control followed by $2 \%$ nutrient spray while essential oil content was on par among the treatments. Oleoresin was highest in $0.5 \%$ spray (Table 4). Results indicate that yield levels can be enhanced in off year (by about 30\%) through nutrient sprays during pre-flowering period, thus reducing the effect of alternate bearing.

In avocado, $\mathrm{P}, \mathrm{Ca}$, and $\mathrm{S}$ were higher, and $\mathrm{Fe}$ was lower in high-yielding years in all rootstocks studied [18]. $\mathrm{N}, \mathrm{P}, \mathrm{K}$ and $\mathrm{Mg}$ contents were affected by crop load, showing lower values following the "on" year in olive [19]. No effect of crop load was observed on micronutrient accumulation in leaves. But in pistachio, minerals and protein concentrations in leaves from fruiting branches were in most cases lower than that of non-fruiting ones [20]. In date palm "on" trees produced boron levels above about $3.5 \mathrm{mg} \cdot \mathrm{kg}^{-1}$, and the "off" trees could be characterized by boron levels below this value [3]. In the present study, most of the nutrient elements were more in leaves in on year compared to that in off year when quantified three months after flowering. This shows that good nutrient build up in leaves at the time of flower initiation may help in good bearing. But the stem (fruiting branch) showed a reverse trend. In stem, all the nutrient levels were high in off year compared to on year. Stem carbohydrate level was also high during off year compared to on year (Table 3). This indicates that nutrient remobilization from stem to the developing fruits must have been affected in off year. It is unclear why this nutrient remobilization is affected. It may be possible that stem may receive some kind of cue as to not to transport nutrients to the developing fruit till a threshold level is reached. But when stem and leaves samples were pooled for carbohydrate estimation, the carbohydrate concentration was more in on year compared to off year (Table 2) implicating that total carbohydrate status of the vine is high during on year compared to off year. Nutrient mobilization problem in alternate bearing trees has been reported in pistachio also. In pistachio, stored carbohydrates increased and remained high after the initial growth flush in off trees. In on trees, stem carbohydrates increased temporarily in early summer, but were mobilized in mid-season during kernel fill, and then increased again after nut harvest [4]. But in pecan, neither root nor shoot $\mathrm{N}, \mathrm{K}$, or nonstructural carbohydrate concentrations appeared to be closely related to the alternate-bearing characteristics.
Table 4. Yield and quality as affected by nutrient spray during spike initiation period.

\begin{tabular}{|c|c|c|c|c|c|}
\hline $\begin{array}{l}\text { Nutrient } \\
\text { solution } \\
(\%)\end{array}$ & $\begin{array}{l}\text { No. of } \\
\text { spikes } \mathrm{m}^{-2}\end{array}$ & $\begin{array}{c}\text { Dry yield } \\
\left(\mathrm{kg} \cdot \mathrm{vine}^{-1}\right)\end{array}$ & $\begin{array}{l}\text { Spike } \\
\text { length } \\
(\mathrm{cm})\end{array}$ & $\begin{array}{c}\text { Essential } \\
\text { oil (\%) }\end{array}$ & $\begin{array}{c}\text { Oleoresin } \\
(\%)\end{array}$ \\
\hline 0.5 & 68 & 4.3 & 12.4 & 2.02 & 9.10 \\
\hline 1.0 & 66 & 5.4 & 12.2 & 2.05 & 8.41 \\
\hline 1.5 & 70 & 4.9 & 12.1 & 1.89 & 8.62 \\
\hline 2.0 & 60 & 3.9 & 11.5 & 1.82 & 8.75 \\
\hline Control & 54 & 3.8 & 10.3 & 2.05 & 8.72 \\
\hline $\mathrm{CD}(0.05)$ & 2.22 & 0.53 & 0.71 & NS & 0.62 \\
\hline
\end{tabular}

Results of the present study indicated that most of the metabolites and nutrient elements were more in leaves at the time of flowering in on year. This lead us to think that we may be able to reduce the alternate bearing effect if metabolic status of the plant is improved before flowering in the ensuing year (which is supposed to be off year) through nutrient supplements. So, we took up spray of complex fertilizer 19:19:19 (per cent N:P:K) @ 0.5\% to $2 \%$ three times at 3 weeks interval from flower primordial initiation to flowering period. Flowering started 8 - 10 days after the last spray. We found that, as expected, spraying of complex fertilizer reduced the alternate bearing effect. All the concentrations except 2\% spray significantly increased dry berry yield per vine compared to water spray. The increase in yield was maximum (29\%) in $1 \%$ spray over water spray. Use of nutrient spray to reduce the impact of alternate bearing has been reported in a few other crops also. Urea spraying along with autumn nitrogen application, as well as spring pruning reduced the alternate bearing cycle in Satsuma mandarin in Iran [21]. But in pecan, low alternate bearing habit of the cultivars was associated with their ability to produce as many or more flowers and flowering shoots the next year on previously bearing terminal shoots compared with previously vegetative shoots. In high alternate-bearing cultivars, return bloom of bearing terminal shoots was suppressed relative to their vegetative shoots [22].

There are many studies reporting increased yields due to foliar application of fertilizers just prior to flowering, flowering and early seed filling stages. For instance, in rice, plant height, dry matter production, number of tillers, yield attributes and yield of grain and straw were highest with recommended integrated nutrient management (INM) practice $+2 \%$ urea phosphate spray at panicle initiation and 10 days later [23]. Combined application of $2 \%$ DAP $+100 \mathrm{ppm}$ salicylic acid $+0.05 \%$ sodium molybdate sprayed during vegetative as well as flowering stages increased the yield attributes in green gram 
[24]. Application of thiourea (1000 ppm) at vegetative and flowering stages in coriander significantly increased the seed $(24.6 \%)$ and straw yields and total uptake of $\mathrm{N}$, $\mathrm{P}$ and $\mathrm{K}$ as compared to control [25]. In Valencia orange, foliar spray of $0.5 \%$ and $1 \%$ urea just 9 weeks before full bloom promoted flower formation, while 6 weeks before full bloom resulted in thicker ovary with higher percentage of fruit set compared to control. Urea spray @ 1\% had more impact than $0.5 \%$ spray [26]. Foliar application of $2 \%$ potassium nitrate, $2 \%$ urea and $2 \%$ muriate of potash at weekly intervals starting from flowering, recorded increased seed yields of cotton to the extent of $36.3 \%$, $27.2 \%$ and $22.4 \%$ respectively over control [27]. But in Jonsok strawberry plants, foliar fertilization during flowering and rapid growth in spring was effective when there was stress caused by unfavourable conditions in spring [28]. These studies indicate the possibility that yields could be increased in on year also by adopting nutrient sprays during these stages.

\section{Conclusion}

To conclude, alternate bearing habit observed in Panniyur-1 variety of black pepper seems to be controlled by carbohydrate pool and nutrients availability at the time of floral primordial initiation. This carbohydrate pool in combination with plant hormones, auxin and cytokinin to some extent may play a role in flowering and fruit set in black pepper, though it is not very obvious from the study. Remobilization of stem reserves seems to be affected in off year. Leaf had higher concentration of most of mineral nutrients compared to stem. Nutrient element content was also more in the stem during off year compared to on year while in leaves it was more during on year compared to off year. Spraying of $1 \%$ solution of complex fertilizer 19:19:19 (\%N:P:K) three times at an interval of 3 weeks (from flower primordial to flower initiation period) doubled the yield in off year. So future studies may be directed more towards nutrient management during off year to obtain higher yields and measures to achieve higher remobilization into developing berries and enhancement of hormone levels through exogenous supplement during flower primordial initiation and early flowering stages during off year to counter the alternate bearing effect.

\section{Acknowledgements}

Authors sincerely acknowledge the Director, Indian Institute of Spices Research, Calicut, Kerala for providing the facilities to conduct the study. Authors also thank Mr Jayaraj, owner of the plantation for all the support to conduct the study at Murugarajendra Estate.

\section{REFERENCES}

[1] E. E. Goldschmidt, "Regulatory Aspects of Alternate Bearing in Fruit Trees," Italus Hortus, Vol. 12, No. 1, 2005, pp. 11-17.

[2] M. W. Smith, C. T. Rohla and N. O. Maness, "Correlations of Crop Load and Return Bloom with Root and Shoot Concentrations of Potassium, Nitrogen, and Nonstructural Carbohydrates in Pecan," Journal of the American Society for Horticultural Science, Vol. 132, No. 1, 2007, pp. 4451.

[3] A. E. Pillay, J. R. Williams, M. O. El-Mardi, S. M. Hassan and A. Al-Hamdi, "Boron and the Alternate-Bearing Phenomenon in the Date Palm (Phoenix dactylifera)," Journal of Arid Environments, Vol. 62, No. 2, 2005, pp. 199207.

[4] T. M. Spann, R. H. Beede and T. M. Dejong, "Seasonal Carbohydrate Storage and Mobilization in Bearing and Non-Bearing Pistachio (Pistacia vera) Trees," Tree Physiology, Vol. 28, No. 2, 2008, pp. 207-213. http://dx.doi.org/10.1093/treephys/28.2.207

[5] S. N. Vemmos, "Alternate Bearing and the Possible Role of Carbohydrates in Bud Abscission of Pistachio (Pistacia vera L.)," In: G. Zakynthinos, Ed., XIV GREMPA Meeting on Pistachios and Almonds, Zaragoza: CIHEAM /FAO/AUA/TEI Kalamatas/NAGREF, Options Méditerranéennes, Série A, Séminaires Méditerranéens, No. 94 2010, pp. 9-18.

[6] S. Sadashivam and A. Manickam, "Biochemical Methods for Agricultural Sciences,” Wiley, New Delhi, 1992.

[7] K. Aniket, P. Pankaj, K. Ankita, G. Kanchanganga and H. Abhay, "Auxin-Like Activity of Extract from Hypertrophied Tissue of Acacia eburnea Infected with Ravenelia esculenta," Plant Cell Tissue and Organ Culture, Vol. 94, No. 1, 2008, pp. 101-104.

[8] E. Glickmann and Y. Dessaux, "A Critical Examination of the Specificity of the Salkowski Reagent for Indolic Compounds Produced by Phytopathogenic Bacteria," Applied Environmental Microbiology, Vol. 61, No. 2, 1995, pp. 793-796.

[9] ASTA, "American Spice Trade Association (ASTA) Official Analytical Methods," 2nd Edition, American Spice Trade Association, New York, 1968.

[10] M. H. Jyothi, R. Soppin and S. Ekbote, "Biochemical Changes in the Leaf of Bearing and Nonbearing Trees of Some Mango (Mangifera indica L.) Varieties/Hybrids," Advances in Agricultural Research in India, Vol. 10, 2000, pp. 17-23.

[11] K. S. Krishnamurthy and B. Chempakam, "Investigation on the Influence of Seedling's Physiological Attributes on Productivity in Black Pepper," Indian Journal of Horticulture, Vol. 66, No. 1, 2009, pp. 95-100.

[12] M. S. Nejad and A. Niroomand, "Carbohydrate Content and Its Roles in Alternate Bearing in Olive," Pakistan Journal of Biological Sciences, Vol. 10, No. 16, 2007, pp. 2744-2747.

http://dx.doi.org/10.3923/pjbs.2007.2744.2747

[13] C. Monerri, A. Fortunato-Almeida, R. V. Molina, S. G. Ne- 
bauer, A. García-Luis and J. L. Guardiola, "Relation of Carbohydrate Reserves with the Forthcoming Crop, Flower Formation and Photosynthetic Rate, in the Alternate Bearing 'Salustiana' Sweet Orange (Citrus sinensis L.)," Scientia Horticulturae, Vol. 129, No. 1, 2011, pp. 71-78. http://dx.doi.org/10.1016/j.scienta.2011.03.009

[14] F. Nishikawa, M. Iwasaki, H. Fukamachi, K. Nonaka, A. Imai, F. Takishita, T. Yano and T. Endo, "Fruit Bearing Suppresses Citrus FLOWERING LOCUS T Expression in Vegetative Shoots of Satsuma Mandarin (Citrus unshiu Marc.)," Journal of the Japanese Society for Horticultural Science, Vol. 81, No. 1, 2012, pp. 48-53. http://dx.doi.org/10.2503/ijshs1.81.48

[15] Y. Okay, N. T. Güneş and A. İ. Köksal, "Free Endogenous Growth Regulators in Pistachio (Pistacia vera L.)," African Journal of Agricultural Research, Vol. 6, No. 5, 2011, pp. 1161-1169.

[16] I. Baktir, S. Ulger, L. Kaynak and D. G. Himelrick, "Relationship of Seasonal Changes in Endogenous Plant Hormones and Alternate Bearing of Olive Trees," Hort Science, Vol. 39, No. 5, 2004, pp. 987-990.

[17] M. Hegele, C. Sritontip, A. Chattrakul, P. Tiyayon, D. Naphrom, K. Sringarm, P. Sruamsiri, P. Manochai and J. N. Wünsche, "Hormonal Control of Flower Induction in Litchi and Longan," Acta Horticulturae, Vol. 863, 2010, pp. 305-314.

[18] M. V. Mickelbart, G. S. Bendera, G. W. Witney, C. Adams and M. L. Arpaia, "Effects of Clonal Rootstocks on 'Hass' Avocado Yield Components, Alternate Bearing, and Nutrition," Journal of Horticultural Science \& Biotechnology, Vol. 82, No. 3, 2007, pp. 460-466.

[19] R. Fernández-Escobar, R. Moreno and M. Garci'a-Creus, "Seasonal Changes of Mineral Nutrients in Olive Leaves during the Alternate-Bearing Cycle," Scientia Horticulturae, Vol. 82, No. 1-2, 1999, pp. 25-45. http://dx.doi.org/10.1016/S0304-4238(99)00045-X

[20] M. E. Amiri, "Physiological Influence of $\mathrm{N}$ in preventing of Alternate-Bearing of Pistachio (Pistacia vera cv. Kalleh-Ghuchi)," Journal of Food, Agriculture \& Environ- ment, Vol. 7, No. 3, 2009, pp. 301-305.

[21] A. A. Kangarshahi, G. Savaghebi and N. A. Amiri, "Alleviation of Alternate Bearing in Satsuma Mandarin by Use of Nitrogen Management and Application of Pruning in East of Maz Andaran Province," Iranian Journal of Horticultural Science, Vol. 42, No. 3, 2012, pp. 217-225.

[22] C. T. Rohla, M. W. Smith, N. O. Maness and W. Reid, “A Comparison of Return Bloom and Nonstructural Carbohydrates, Nitrogen, and Potassium Concentrations in Moderate and Severe Alternate-Bearing Pecan Cultivars," Journal of the American Society for Horticultural Science, Vol. 132, No. 2, 2007, pp. 172-176.

[23] N. Jagathjothi, P. Muthukrishnan and M. M. Amanullah, "Influence of Foliar Nutrition on Growth and Yield of Transplanted Rice," Madras Agricultural Journal, Vol. 99, No. (4/6), 2012, pp. 275-278.

[24] R. Kuttimani and A. Velayutham, "Foliar Application of Nutrients Enhances the Yield Attributes and Nutrient Uptake of Greengram," Agricultural Science Digest, Vol. 31, No. 3, 2011, pp. 202-205.

[25] L. R. Balai and G. L. Keshwa, "Effect of Thiourea on Yield and Nutrient Uptake of Coriander (Coriandrum sativum L.) Varieties under Normal and Late Sown Conditions," Journal of Spices and Aromatic Crops, Vol. 20, No. 1, 2011, pp. 34-37.

[26] S. A. Chermahini, N. Moallemi, D. A. Nabati and A. R. Shafieizargar, "Winter Application of Foliar Urea Can Promote Some Quantitative and Qualitative Characters of Flower and Fruit Set of Valencia Orange Trees," Journal of Food, Agriculture \& Environment, Vol. 9, No. 1, 2011, pp. 252-255.

[27] M. S. Brar and A. S. Brar, "Foliar Nutrition as a Supplement to Soil Fertilizer Application to Increase Yield of Upland Cotton (Gossypium hirsutum)," Indian Journal of Agricultural Sciences, Vol. 74, No. 9, 2004, pp. 472-475.

[28] K. Karp and M. Starast, "Effects of Springtime Foliar Fertilization on Strawberry Yield in Estonia," Acta Horticulturae, Vol. 594, 2002, pp. 501-505. 